\title{
Komunikasi Non Verbal Anak Autis pada Masa Adaptasi Pra Sekolah
}

\author{
Mutia Rahmi Pratiwi', Lisa Mardiana ${ }^{2}$, Amida Yusriana ${ }^{3}$ \\ ${ }^{1}$ Universitas Dian Nuswantoro, ${ }^{2}$ Universitas Dian Nuswantoro, ${ }^{3}$ Universitas \\ Diponegoro \\ e-mail: ${ }^{1}$ mutia.rahmi@dsn.dinus.ac.id
}

\begin{abstract}
Abstrak
Setiap anak memiliki kehidupan yang beragam begitupula dengan kehidupan para anak autis. Seringkali mereka dianggap anak yang aneh karena sulit fokus pada pembicaraan orang lain dan tidak memiliki ketertarikan dengan dunia sosialnya. Jumlah anak yang menderita autisme pun hingga saat ini belum dapat dipastikan namun diprediksi jumlah penderitanya terus meningkat di setiap tahunnya. Pendidikan menjadi salah satu sarana bagi anak autis memperoleh standarisasi bagaimana mereka berperilaku yang baik sesuai norma di masyarakat. Taman Kanak-Kanak (TK) merupakan jenjang pendidikan non formal pertama bagi anak autis. Namun karena keterbatasan yang dimiliki anak autis, seringkali kegagalan komunikasi pun terjadi dalam proses pembelajaran. Penolakan saat awal memasuki lingkungan Taman KanakKanak pun menjadi hal yang tidak terelakan. Hal ini menjadi daya tarik bagi peneliti untuk mengkaji secara lebih mendalam mengenai perilaku adaptasi anak autis pada jenjang Taman Kanak-Kanak (TK). Penelitian ini merupakan penelitian kualitatif dengan metode fenomenologi. Objek penelitian dilakukan pada tiga orang anak autis, yaitu: $M$, $W$ dan D di SLB Widya Bhakti Semarang. Tujuan penelitian adalah mendeskripsikan bentuk komunikasi non verbal anak autis pada saat memasuki lingkungan barunya yaitu lingkungan Taman Kanak-Kanak (TK).
\end{abstract}

Kata Kunci: Autisme, Komunikasi Non Verbal, Taman Kanak-Kanak (TK)

\begin{abstract}
Every children has distinguished life, likewise the life of the children with autism. Children with autism frequently considered as odd because they seems like having trouble in paying attention and are uninterested to social life. Indonesia does not have the precise number of the children with autism and it has been increased every year. Education is one of the medium for children with autism to learn the standard way of behaviour that socially acceptable. The kindergarten is the first non formal school for children with autism. However, the autism's disability often fails the communication process at school. The rejection will be unavoidable for the first initial meetings. This phenomenon becomes the main attraction for the researcher to analyze the behaviour of children with autism in the kindergarten. This is a qualitative research and using the phenomenology method. The objects of the research is $M, W$ and $D$. They are the children with autism at the informal school of Widya Bhakti Semarang. The aim of this research is to describe the non verbal communication of children with autism as the efforts of adaptation in the kindergarten.
\end{abstract}

Keywords: Autism, Non Verbal Communication, Kindergarten 


\section{PENDAHULUAN}

Autisme merupakan suatu kumpulan sindrom yang mengganggu syaraf. Penyakit ini mengganggu perkembangan anak, diagnosisnya diketahui dari gejalagejala yang tampak dan ditunjukan dengan adanya penyimpangan perkembangan. Gangguan perkembangan pada anak autisme terjadi pada masa kanak-kanak yang membuat anak tidak mampu mengadakan interaksi sosial dan seolah-olah hidup dalam dunianya sendiri (Prasetyono, 2008:11). Autisme merupakan satu dari lima tipe pervasive developmental diorders (PDD) yang ditandai dengan tampilnya abnormalitas pada domain interaksi dan komunikasi, (Priyatna dan Andri, 2011:2).

Penderita autis tidak hanya di Indonesia, namun juga di beberapa negara lainnya termasuk Indonesia. Di indonesia diprediksi jumlah penderita autis dari tahun ke tahun semakin meningkat. Sepuluh tahun yang lalu jumlah penyandang autisme diperkirakan satu per 5.000 anak, tahun 2000 meningkat menjadi satu per 500 anak dan diperkirakan tahun 2010 satu per 300 anak. Pada tahun 2015 diperkirakan satu per 250 anak mengalami gangguan spektrum autis dan terdapat kurang lebih 12.800 anak penyandang autisme dan 134.000 penyandang spektrum autis (https://klinikautis.com).

Anak autis seringkali dianggap berbeda dengan anak-anak normal seusianya. Hal ini dikarenakan berbagai keterbatasan yang mereka miliki sehingga anak-anak autis membutuhkan perlakuan khusus di lingkungan keluarga dan membutuhkan penangan khusus dalam hal pendidikan. Berdasarkan UndangUndang RI, setiap anak berhak untuk mendapatkan pendidikan, tak terkecuali bagi anak-anak kebutuhan khusus. Hak anak berkebutuhan khusus untuk mendapatkan pendidikan diatur dalam UU Republik Indonesia Nomor 23 Tahun 2002 Tentang Perlindungan Anak. Dimana pasal yang mencakup adalah Pasal 9 Ayat 1 dan 2 . Pasal 9 ayat 1 berbunyi "Setiap anak berhak memperoleh pendidikan dan pengajaran dalam rangka pengembangan pribadinya dan tingkat kecerdasannya sesuai dengan minat dan bakatnya". Pasal 9 ayat 2 yang berbunyi "selain hak anak sebagaimana dimaksud dalam ayat (1), khusus bagi anak yang menyandang cacat juga berhak memperoleh pendidikan luar biasa sedangkan bagi anak yang 
memiliki keunggulan juga berhak mendapatkan pendidikan khusus”. Selain itu juga terdapat UU Sistem Pendidikan Nasional (Sisdiknas) No 20 Tahun 2003 mengamanatkan pemerintah untuk menyelenggarakan pendidikan bagi semua masyarakat (http://www.kpai.go.id/).

Pendidikan anak dimulai dari pendidikan non formal yaitu pada jenjang TK (Taman Kanak-Kanak) yang menjadi langkah awal pembelajaran perilaku bagi anak termasuk anak autis. Pada jenjang ini anak autis mulai diajarkan untuk berada di lingkungan baru yaitu lingkungan Taman Kanak-Kanak untuk mengenal selain orangtuanya, yaitu: guru, teman dan orang lain di lingkungan sekolah. Anakpun mulai diajarkan bagaimana bersosialisasi dan bagaimana seharusnya ia berperilaku di depan orang lain. Anak juga belajar proses berkomunikasi melalui pembelajaran untuk patuh pada aturan yang berlaku, diantaranya: waktu jam belajar mengajar dan peraturan-peraturan kelas yang tidak boleh dilanggar. Proses yang dilalui anak pada jenjang TK akan membuat anak mengerti mengenai apa yang boleh dan tidak boleh ia lakukan.

Pembentukan perilaku anak merupakan bekal mendasar agar anak dapat melakukan kegiatan lainnya sesuai norma yang berlaku di masyarakat. Pada jenjang TK, perilaku anak autis akan dibentuk dengan baik sehingga perilaku anak sesuai norma yang berlaku di masyarakat. Ketika anak sudah memahami bagaimana seharusnya ia berperilaku maka lingkungan di sekitarnya akan menerimanya dengan baik. Pada pembentukan perilaku, anak akan mulai diajarkan bagaimana seharusnya berbicara dan bersikap dengan orang lain, menjawab pertanyaan dengan baik, duduk dengan sopan, bagaimana sikap yang harus ditunjukan ketika harus berinteraksi dengan teman sebaya dan hal-hal lain yang berkaitan dengan perilaku anak. Sehingga anak akan dapat membedakan mana yang harus ia lakukan dan yang tidak boleh ia lakukan serta anak dapat membedakan mana yang baik dan buruk.

Anak autis biasanya mengalami kesulitan komunikasi baik komunikasi isyarat (non verbal) maupun komunikasi berbahasa (verbal). Anak autis kurang memahami pembicaraan sehingga terlihat seolah-olah seperti anak dengan gangguan pendengaran. Pada anak autis jelas terjadi defisit dalam kemampuan 
komunikasi dan terjadi penyimpangan berbahasa. Anak autis sedikit menggunakan arti dalam daya ingat dan proses berpikirnya. Percakapan tidak ditandai oleh saling tukar dan timbal balik, pembicaraannya sering mengandung ekolalia segera atau terhambat. Anak dapat berbicara dengan kalimat pendek tetapi bukan merespon pertanyaan, sering disertai pembalikan kata sebutan, monoton, penghindaran kata benda pribadi dan buruknya fleksibilitas dalam bahasa ekspresi anak (Nugraheni, 2008:3).

Berdasarkan hasil observasi di SLB Widya Bhakti Semarang, terjadi beberapa kegagalan komunikasi yang terjadi antara guru dengan anak autis. Diantaranya, pada saat guru mengarahkan anak untuk bersikap menirukannya berdoa, salah seorang anak autis justru mengambil buku dan mencoret-coretnya bahkan ada juga yang memukul-mukul tangannya di meja dan berteriak keras. Saat guru menyuruh anak untuk duduk dengan sopan, anak justru menangis dan memukul gurunya sebagai ungkapan penolakannya. Pada saat anak disuruh untuk mewarnai gambar namun yang anak lakukan justru membuka kertas pembungkus crayon dan membuangnya.

Saat pelajaran kemandirian anak berlangsung, anak diajarkan menggunakan gel rambut yang benar namun yang anak lakukan adalah mengoleskan gel rambut ke kaca dan ada juga yang memainkannya dengan mengoleskan gel rambut ke baju temannya. Penjabaran diatas merupakan contoh bahwa anak autis cenderung menunjukan komunikasi non verbal mereka dari verbalnya dan dalam proses berkomunikasi dengan anak autis terdapat kendala yang menyebabkan apa yang disampaikan tidak sama dengan apa yang diterima. Lalu bagaimana komunikasi non verbal yang ditunjukan oleh anak autis sebagai perilaku adaptasi pada jenjang Taman Kanak-Kanak di SLB Widya Bhakti Semarang? 


\section{PEMBAHASAN}

Jurnal ini menggunakan metodologi fenomenologi, yaitu suatu studi yang memandang bahwa pengetahuan hadir dari kesadaran manusia. Menurut Hogel, cara seseorang memahami suatu obyek atau kejadian adalah dengan mengalaminya sendiri secara sadar. Pengalaman yang dimaksud adalah pengalaman yang timbul dalam kesadaran (intentional experience), (Moustakas,1994:55). Fenomenologi berasumsi bahwa orang-orang secara aktif menginterpretasikan pengalaman-pengalamannya dan mencoba memahami dunia dengan pengalaman pribadinya. Menurut Littlejohn, semua yang seseorang ketahui merupakan bagian dari pengalaman seseorang. Tiga prinsip dasar fenomenologi antara lain: kesadaran, makna suatu hal atau kejadian dalam kehidupan seseorang, dan bahasa sebagai alat menyampaikan dan mengekspresikan pengalaman, (Littlejohn, Stephen W dan Foss Karen A, 2009:39).

Riset ini dilakukan di SLB Widya Bhakti Semarang dengan jumlah subjek penelitian 3 orang anak autis, yaitu D, W dan M. Peneliti memahami pengalaman yang dilalui anak autis melalui deskripsi guru mereka di jenjang TK. Selain itu, peneliti juga mengikuti kegiatan yang berlangsung di sekolah selama 4 bulan sehingga melihat secara langsung perilaku ketiga anak autis tersebut. Anak autis yang memiliki keterbatasan dalam berkomunikasi menyebabkan peneliti membutuhkan bantuan dari pihak guru untuk mendeskripsikan sikap yang anakanak tunjukan.

\section{Autism}

Kata autism berasal dari bahasa Yunani Kuno atau Greek yang berarti self atau diri sendiri. Anak autis memiliki kecenderungan hidup dalam dunianya sendiri. Anak dengan gangguan autisme mempunyai kesulitan untuk belajar berkomunikasi secara verbal dan non verbal. Beberapa anak autis cenderung suka menyakiti diri sendiri dan melakukan kegiatan gerak yang sama selama ber jamjam, (Delphie, Bandi, 2009:5). Kelainan yang dialami sangat mempengaruhi diri anak dalam beberapa aspek lingkungan kehidupan dan pengalaman- 
pengalamannya. Oleh karena itu anak dengan sindrom autisme dikenal juga sebagai pervasive developmental disorders (PDD).

Beberapa gejala klinis yang dijumpai pada anak autis adalah: gangguan fisik dan perilaku. Gangguan fisik mencakup kegagalan atau kelainan maturasi otak sehingga terjadi dominasi selebral yang abnormal dan adanya infeksi saluran nafas bagian atas, infeksi telinga, sendawa berlebihan, kejang demam dan konstipasi. Gangguan perilaku mencakup:

- Gangguan dalam interaksi sosial. Anak tidak mampu berhubungan secara normal baik dengan orangtua maupun oranglain.

- Gangguan komunikasi dan bahasa. Kemampuan komunikasi dan bahasa sangat lamban bahkan tidak ada sama sekali.

- Gangguan perilaku motoris. Terdapat gerakan yang dilakukan berulangulang.

- Gangguan emosi, perasaan dan efek. Seringkali muncul perubahan perasaan secara tiba-tiba.

- Gangguan persepsi sensoris. Suka mencium atau menjilat benda dan tidak merasa sakit saat tubuhnya terluka, (Nugraheni, 2008:23).

\section{Pendidikan TK sebagai Awal Pembentukan Perilaku}

Pendidikan merupakan media untuk belajar mengenai bagaimana bersosialisasi, menghormati dan belajar mengenai moral dan perilaku yang seharusnya ia miliki. Ia mulai beradaptasi dengan berbagai hal baru dari segi lingkungan, teman dan orang-orang baru (Purwanto, 2006:10). Pendidikan non formal Taman Kanak-Kanak yang pertama kali dilalui anak adalah pada jenjang TK (Taman Kanak-Kanak). Terdapat banyak anak yang merasa takut pada saat pertama kali masuk ke kelas pada jenjang ini yang disebabkan oleh banyak faktor, diantaranya bertemu dengan guru sebagai orang asing, belum terbiasa bersosialisasi dan bergaul dengan teman-teman sebayanya, (Marijani, 2003:35). 
Pada awal anak masuk kelas, anak akan mengalami keengganan untuk diatur dan pada tahap ini terjadi proses adaptasi serta proses pembentukan perilaku anak. Penolakan yang dilakukan anak menjadi kendala yang harus diselesaikan oleh pihak guru sehingga pada akhirnya anak akan dapat berkembang dengan perilaku yang baik dan dapat meninggalkan kebiasaan buruknya. Ketika proses belajar mengajar sudah berlangsung maka anak harus taat pada aturan yang berlaku di sekolah.

Pada jenjang TK, perkembangan moral pada anak masih dalam tingkatan yang rendah karena perkembangan intelektual anak-anak belum mencapai titik dimana anak dapat mempelajari secara meneyeluruh atau menerapkan prinsip mendasar mengenai benar dan salah. Anak pada usia 4 tahun juga tidak memiliki dorongan untuk mengikuti peraturan-peraturan karena belum memahami manfaat yang akan diperoleh ketika seseorang taat aturan sebagai bagian dari anggota kelompok sosial.

\section{Komunikasi Non Verbal}

Komunikasi tidak hanya dapat dilakukan melalui berbicara atau pengungkapan diri secara verbal karena inti komunikasi adalah penyampaian pesan oleh pengirim yang dapat diterima dengan baik oleh si penerima pesan. Pesan dapat disampaikan dengan baik tidak hanya terbatas pada satu cara. Pesan juga dapat disampaikan melalui bahasa isyarat, gerakan tubuh, pertukaran simbol dan komunikasi non verbal lainnya. Hal yang terpenting adalah bagaimana pesan dapat dipahami oleh semua orang secara universal (Puspita, Dyah, 2004: 116).

Kode non verbal memiliki dimensi semantik, sintaksis dan pragmatik. Semantik mengacu pada makna dari sebuah tanda. Sintaksis mengacu pada metode bagaimana tanda-tanda tersebut disusun ke dalam sistem dengan tanda lainnya. Pragmatik mengacu pada pengaruh atau perilaku yang dimunculkan oleh sebuah tanda atau sekelompok tanda. Tidak seperti bentuk verbal, makna yang diterapkan pada non verbal terkungkung oleh konteks atau ditentukan dalam bagian situasi yang mereka hasilkan. Baik bahasa maupun non verbal mengizinkan beberapa tanda yang berhubungan ke dalam sebuah variasi kompleks 
yang hampir tidak terbatas dari pengungkapan makna, (Littlejohn, Stephen W dan Foss Karen A, 2009:159).

Setiap anak autis memiliki satu pokok permasalahan yang sama yaitu pada masalah komunikasi. Anak memiliki kesulitan dalam mengungkapkan apa yang ia inginkan karena kurangnya ketertarikan terhadap lawan bicara, kurang berfungsinya syaraf sensorik dan motorik anak, permasalahan pada IQ nya dan berbagai masalah lainnya. Anak autis cenderung menggunakan bahasa non verbal untuk berkomunikasi walaupun bahasa tersebut hanya dimengerti oleh lingkungan terdekatnya seperti orang tua maupun saudara sekandungnya.

Kesulitan anak autis dalam berkomunikasi membuat orang-orang di sekitarnya harus menebak-nebak apa yang ia inginkan. Hal ini juga dikarenakan anak tidak paham terhadap pesan yang disampaikan orang lain sehingga anak juga enggan mengungkapkan keinginannya. Keterbatasan untuk memahami dirinya sendiri membuat anak autis terkadang senang berteriak sendiri, mengulang katakata yang seriang ia dengar, menangis sendiri lalu tiba-tiba tertawa tanpa sebab yang jelas. Keterbatasan yang dimiliki anak autis membuat peranan komunikasi sangat penting bagi anak autis, yaitu: anak dapat mengontrol emosinya, mengerti bagaimana berperilaku yang baik serta bagaimana seharusnya berbicara dengan sopan.

Komunikasi yang sering dilakukan akan membangun emosional anak untuk lebih mengerti artinya kasih sayang merupakan cara yang efektif dan memberikan dorongan bagi anak agar dapat berkomunikasi secara lebih efektif. Anak autis tidak selalu menggunakan bahasa verbal untuk mengungkapkan sesuatu namun ia menggunakan bahasa non verbal untuk menunjukan apa yang ia inginkan. Bahasa non verbal yang digunakan anak autis merupakan cara yang digunakan agar orang lain dapat memahami komunikasi anak autis.

Komunikasi non verbal merupakan pesan yang dikomunikasikan melalui gerak tubuh, gerakan mata, ekspresi wajah, sosok tubuh, penggunaan jarak atau ruang, kecepatan dan volume suara bahkan keheningan. Tujuan dari pesan non verbal adalah meningkatkan pemahaman mengenai sifat dan fungsi komunikasi non verbal, meningkatkan pemahaman terhadap diri sendiri dan orang lain sebagai 
seseorang yang menyampaikan komunikasi dan meningkatkan kemampuan berkomunikasi agar lebih efektif, (Devito, A. Joseph, 1997:176).

Komunikasi non verbal memiliki banyak bentuk diantaranya:

1. Kinesics. Merupakan suatu nama teknis bagi studi mengenai gerakan tubuh yang digunakan dalam komunikasi. Gerakan tubuh merupakan perilaku non verbal dimana komunikasi terjadi melalui gerakan tubuh seseorang atau bagian-bagian tubuh. Gerakan tubuh terdiri dari: kontak mata, ekspresi wajah, gerak isyarat, postur atau perawakan dan sentuhan.

2. Paralanguage. Merupakan "suara" non verbal apa yang kita dengar bagaimana sesuatu dikatakan. Terdapat empat karakteristik vokal, yaitu:

- Pola Titinada atau Pitch. Merupakan tinggi atau rendahnya nada vokal.

- Volume. Merupakan keras atau lembutnya nada.

- Kecepatan. Mengacu kepada kecepatan pada saat orang berbicara.

- Kualitas. Merupakan bunyi dari suara seseorang, (Budyatna, 2011:131).

Ray Birdwhistell diakui sebagai orang yang pertama dibalik bidang kinesis. Dalam bukunya, Kinesis and Context, Birdwhistell mengurutkan tujuh asumsinya yang menjadi dasar teorinya dalam bahasa tubuh, yaitu:

1. Semua gerakan tubuh memiliki makna penting dalam konteks komunikasi. Seseorang selalu dapat memberikan makna terhadap aktivitas tubuh.

2. Perilaku dapat dianalisis karena telah diatur dan pengaturan ini dapat dikupas dengan analisis sistematis.

3. Walaupun aktivitas tubuh memiliki keterbatasan secara biologis, kegunaan pergerakan tubuh dalam interaksi dianggap menjadi sebuah bagian dari sistem sosial.

4. Orang dipengaruhi oleh aktivitas tubuh orang lain yang terlihat.

5. Cara aktivitas tubuh yang berfungsi dalam komunikasi dapat diselidiki.

6. Makna yang terungkap dalam hasil penelitian kinesis berasal dari perilaku yang telah dikaji.

7. Seseorang yang menggunakan aktivitas tubuh akan memiliki ciri-ciri idiosyncratic, tetapi juga akan menjadi bagian sosial yang besar bersama- 
sama dengan yang lainnya, ((Littlejohn, Stephen W dan Foss Karen A, 2009:159).

\section{Perilaku Adaptasi Anak Autis}

Penyesuaian diri dalam bahasa aslinya dikenal dengan istilah adjustment atau personal adjustments. Menurut Schneiders (1984) penyesuaian diri ditinjau dari tiga sudut pandang, yaitu: Penyesuaian diri sebagai adaptasi (adaptation); Penyesuaian diri sebagai bentuk konformitas (conformity); dan Penyesuaian diri sebagai usaha penguasaan. Dilihat dari latar belakang, pada mulanya penyesuaian diri diartikan sama dengan adaptasi. Adaptasi lebih mengarah pada penyesuaian diri dalam arti fisik, fisiologis atau biologis. Jika penyesuaian diri hanya diartikan secara fisik maka cenderung diartikan sebagai usaha mempertahankan diri secara fisik atau survival. Bila penyesuaian diartikan dalam arti psikologis maka ada kompleksitas kepribadian individu serta adanya hubungan kepribadian individu dengan lingkuangannya, (Ali, Mohammad dan Mohammad Asrori, 2009:173).

Penyesuaian diri merupakan salah satu bentuk interaksi yang didasari oleh adanya penerimaan atau saling mendekatkan diri. Individu akan melakukan berbagai bentuk kegiatan penyesuaian diri yang disesuaikan dengan diri individu (autoplastic), atau dapat juga hal-hal yang ada pada lingkungan diubah sesuai dengan kebutuhan individu (alloplastic) atau penyesuaian diri dengan keduanya secara serempak. Bentuk penyesuaian diri autoplastic adalah peniruan atau imitasi dan belajar, (Sukma Dinata, 2005:57).

Pembelajaran anak pada saat pertama kali terdiri dari proses adaptasi anak, anak dipaksa untuk melakukan perintah dan anak diajarkan untuk bersosialisasi. Dalam penelitian ini ditemukan bahwa setiap anak yang memasuki lingkungan pendidikan akan mengalami proses adaptasi terlebih dahulu. Anak tidak bisa langsung merasa nyaman di tempat yang baru dan berbeda dengan lingkungan saat berada di rumah. Anak memerlukan waktu untuk terbiasa mematuhi aturan yang berlaku, terbiasa berada di sekitar teman-teman yang awalnya tidak ia kenal dan terbiasa mematuhi perintah dan larangan yang diberikan oleh guru. 
Semua pembelajaran yang berlangsung bagi anak autis selalu diawali dengan paksaan. Kesulitan anak untuk beradaptasi menyebabkan semua harus diawali dengan paksaan. Walaupun awalnya anak menolak namun apabila sudah terbiasa maka anak akan memahami perintah yang diberikan guru dan menjadikannya sebagai kebiasaan. Merubah kebiasaan buruk anak autis bukan merupakan hal yang mudah sehinggga awal pembelajaran harus diberikan dengan cara yang tegas dan pemaksaan. Hal ini dilakukan dengan berbagai pertimbangan, diantaranya: kemampuan anak, gangguan yang dimiliki anak dan semua metode bertujuan untuk perkembangan anak.

Berdasarkan penelitian yang dilakukan, anak mengalami ketakutan akan lingkungan barunya sehingga muncul berbagai sikap yang menunjukan penolakan. Sikap yang ditunjukan anak tidak sama, tergantung pada karakteristik dan kemampuan masing-masing anak. Penolakan anak ditunjukan dengan menolak masuk kelas, menolak untuk duduk tenang dan berada di kelas serta menolak untuk mematuhi perintah yang diberikan oleh guru. Hal ini merupakan kondisi yang selalu dialami anak saat pertama kali berada di situasi dan tempat yang baru.

Anak autis memiliki permasalahan interaksi sosial yang terlihat dari sikap anak yang cenderung cuek dengan keberadaan orang-orang di sekitarnya dan anak terlihat hidup di dalam dunianya sendiri. Permasalahan ini merupakan alasan mendasar perlunya mengajarkan anak autis untuk mengenal teman-teman seusianya dan bermain bersama dalam kondisi tertentu. Cara yang dilakukan guru dalam mengajarkan anak bersosialisasi adalah menyuruh seluruh murid keluar dari kelas pada saat jam istirahat dan menyatukan mereka dalam ruangan bermain. Hal ini dilakukan dengan tujuan untuk mengajarkan anak autis agar mau bermain bersama teman-temannya. Namun pada kenyataannya masih terdapat beberapa anak autis yang duduk sendiri dan menganggap tidak ada orang lain di dekatnya.

Berdasarkan fungsi dari komunikasi non verbal, anak autis lebih menggunakan bahasa non verbal untuk menggantikan pesan verbal. Hal ini dikarenakan anak autis mengalami kesulitan untuk mengungkapkan apa yang ia inginkan dan ia rasakan. Anak juga memiliki perbendaharaan kata yang sangat terbatas. Seringkali ketika muncul kata-kata dari anak hanya bersifat pengulangan 
karena seringnya mendengar kata tersebut. Anak autis memiliki emosi yang labil, terlihat dari sikap anak yang bisa tiba-tiba marah hingga berteriak, lalu menangis dan tertawa tanpa sebab yang jelas. Anak autis memiliki kecenderungan untuk melakukan apapun yang ia inginkan tanpa mempedulikan hal tersebut benar atau salah, sesuai atau tidak dengan aturan yang berlaku.

Berikut ini komunikasi non verbal yang ditunjukan ketiga anak autis sebagai bentuk sikap adaptasi pada saat Taman Kanak-Kanak (TK):

Tabel 1. Komunikasi Non Verbal Anak Autis sebagai Sikap Adaptasi

\begin{tabular}{|c|c|c|c|c|}
\hline No & $\begin{array}{l}\text { Nama } \\
\text { Anak }\end{array}$ & $\begin{array}{l}\text { Bentuk } \\
\text { Komunikasi } \\
\text { Non Verbal } \\
\end{array}$ & $\begin{array}{l}\text { Jenis } \\
\text { Komunikasi } \\
\text { Non Verbal }\end{array}$ & Sikap yang ditunjukan anak \\
\hline \multirow[t]{6}{*}{1} & \multirow[t]{6}{*}{$\mathrm{M}$} & \multirow[t]{4}{*}{ Kinesics } & $\begin{array}{l}\text { Gerak } \\
\text { tubuh }\end{array}$ & $\begin{array}{ll}\text { - } & \text { Menolak masuk ke dalam kelas dengan } \\
\text { tubuh yang enggan diajak masuk kelas } \\
\text { - } & \text { Memanjat jendela yang berada di ujung } \\
\text { kelas } \\
\text { - } \quad \text { Memanjat rak buku yang berada di } \\
\text { sudut kelasnya } \\
\text { - } \\
\text { Menuangkan air ke bajunya hingga } \\
\text { basah kuyup }\end{array}$ \\
\hline & & & $\begin{array}{l}\text { Kontak } \\
\text { mata }\end{array}$ & $\begin{array}{l}\text { - M melakukan kontak mata hanya saat } \\
\text { guru memanggil namanya dengan suara } \\
\text { lantang dan cenderung membentak } \\
\text { - M seringkali melihat lingkungan } \\
\text { sekitarnya dengan tatapan kosong tanpa } \\
\text { makna }\end{array}$ \\
\hline & & & $\begin{array}{l}\text { Ekspresi } \\
\text { Wajah }\end{array}$ & $\begin{array}{l}\text { - Menunjukan ekspresi wajah marah saat } \\
\text { mendengar kata "Clok.. Clok.." }\end{array}$ \\
\hline & & & $\begin{array}{l}\text { Gerak } \\
\text { Isyarat }\end{array}$ & $\begin{array}{l}\text { - Menunjukan kemarahan dengan } \\
\text { menendang meja tulisnya, memuku } \\
\text { guru atau temannya dan menangis } \\
\text { sekeras-kerasnya } \\
\text { - Menunjuk dengan tangan ke arah } \\
\text { kemaluanya selesai buang air kecil atau } \\
\text { besar }\end{array}$ \\
\hline & & \multirow[t]{2}{*}{ Paralanguage } & $\begin{array}{l}\text { Pola } \\
\text { Titinada } \\
\text { atau Pitch }\end{array}$ & 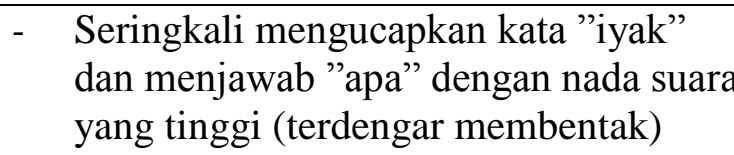 \\
\hline & & & Kecepatan & $\begin{array}{l}\text { Kata yang diucapkan cenderung cepa } \\
\text { dan hanya mengulang bukan menjawab }\end{array}$ \\
\hline
\end{tabular}




\begin{tabular}{|c|c|c|c|c|}
\hline & & & & pertanyaan \\
\hline \multirow[t]{5}{*}{2} & \multirow[t]{5}{*}{ W } & \multirow[t]{4}{*}{ Kinesics } & $\begin{array}{l}\text { Gerak } \\
\text { tubuh }\end{array}$ & $\begin{array}{ll}\text { - } & \text { Memberontak saat guru memintanya } \\
\text { untuk masuk ke dalam kelas } \\
\text { - } & \text { Tidak mau duduk di bangku yang sudah } \\
\text { disediakan di kelas belajar mengajar } \\
\text { namun duduk di lantai dan menangis. } \\
\text { - } \\
\text { Memainkan saklar lampu yang berada } \\
\text { di tembok kelasnya dan memainkan } \\
\text { kipas angin yang berada di atas meja } \\
\text { ibu guru. } \\
\text { Tidak mau berbicara. }\end{array}$ \\
\hline & & & $\begin{array}{l}\text { Kontak } \\
\text { mata }\end{array}$ & 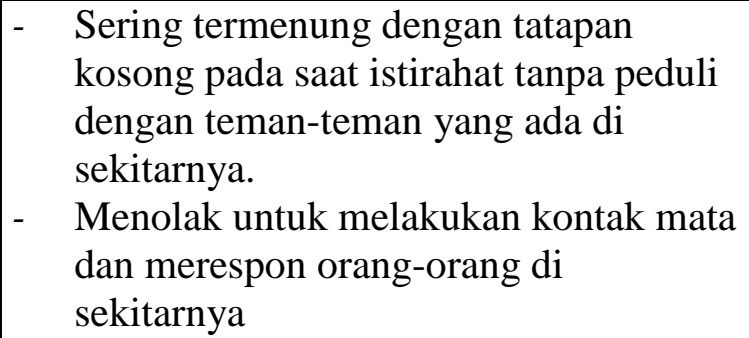 \\
\hline & & & $\begin{array}{l}\text { Ekspresi } \\
\text { Wajah }\end{array}$ & $\begin{array}{l}\text { - Seringkali terlihat murung (tidak ceria/ } \\
\text { tidak senang) }\end{array}$ \\
\hline & & & $\begin{array}{l}\text { Gerak } \\
\text { Isyarat }\end{array}$ & $\begin{array}{l}\text { - Menunjukan sikap jahil dengan sikap } \\
\text { tiba-tiba mencubit dan menggigit } \\
\text { tangan temannya }\end{array}$ \\
\hline & & Paralanguage & $\begin{array}{l}\text { Pola } \\
\text { Titinada } \\
\text { atau Pitch }\end{array}$ & $\begin{array}{ll}\text { - } & \text { Memberikan respon dengan suara yang } \\
\text { rendah (cenderung tidak terdengar) } \\
\text { - } \\
\text { Tidak menunjukan penekanan nada saat } \\
\text { berbicara }\end{array}$ \\
\hline \multirow[t]{3}{*}{3} & \multirow[t]{3}{*}{$\mathrm{D}$} & \multirow[t]{3}{*}{ Kinesics } & $\begin{array}{l}\text { Gerak } \\
\text { tubuh }\end{array}$ & $\begin{array}{ll}- & \text { Menolak masuk kelas dengan memeluk } \\
& \text { erat ibunya saat mengantar } \\
\text { - } & \text { Sering duduk tenang di ujung ruangan } .\end{array}$ \\
\hline & & & $\begin{array}{l}\text { Kontak } \\
\text { mata }\end{array}$ & $\begin{array}{l}\text { - Memandang sekitar dengan tatapan } \\
\text { kosong. }\end{array}$ \\
\hline & & & $\begin{array}{l}\text { Ekspresi } \\
\text { Wajah }\end{array}$ & 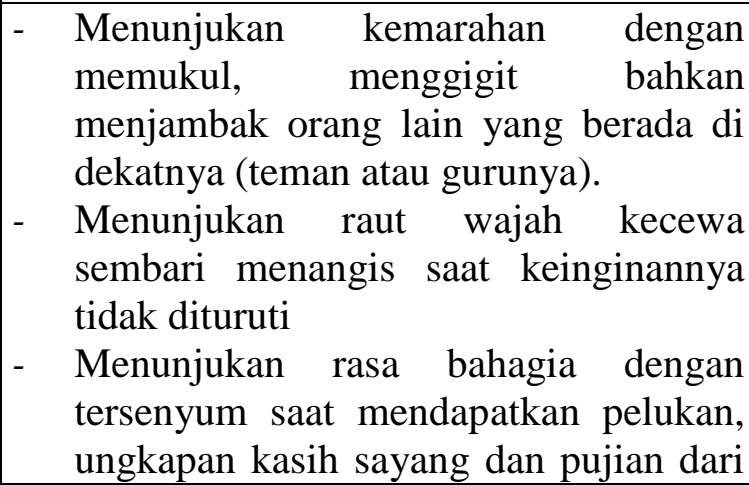 \\
\hline
\end{tabular}




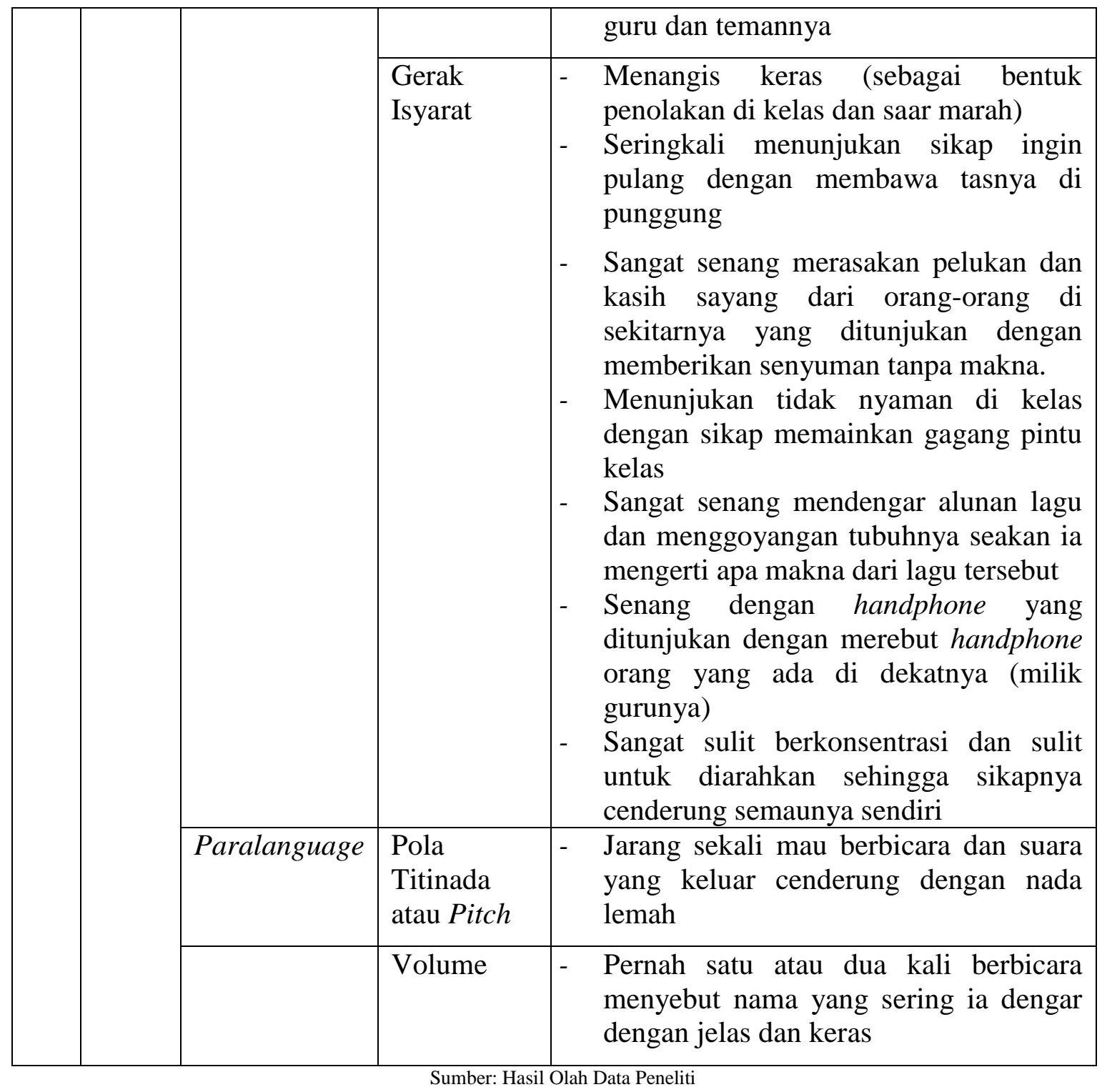

\section{SIMPULAN}

Saat anak autis pertama kali masuk TK, ia memiliki perilaku yang belum terbentuk. Sehingga sikap yang ditunjukan anak masih sikap yang semaunya sendiri. Pendidikan anak autis dimulai sejak Taman Kanak-Kanak (TK) dimana pada jenjang ini merupakan dasar yang penting dalam pembentukan perilaku anak. Anak yang awalnya hanya mengerti lingkungan keluarga berikut dengan aturan di dalamnya, kini anak mulai belajar dalam lingkungan barunya yaitu lingkungan Taman Kanak-Kanak (TK). Penolakan pada anak pun menjadi tak 
terelakan karena seakan mereka dipaksa untuk berada di lingkungan yang lain bersama dengan orang baru dan aturan baru di dalamnya.

Hasil penelitian menunjukan bahwa ketiga anak autis menunjukan bentuk komunikasi non verbal kinesic yang ditunjukan melalui gerak tubuh, kontak mata, ekspresi tubuh dan gerak isyarat. Ketiga anak menunjukan gerak tubuh yang beragam sebagai bentuk penolakan. M menunjukan penolakan dengan aktivitas memanjat rak buku dan jendela serta membuat kericuhan (mengguyurkan air ke tubuh). Hal ini berbeda dengan $\mathrm{W}$ yang menolak dengan menunjukan ketidaknyamannya dengan sikap menolak duduk di bangku kelas dan menangis. Sedangkan D justru menunjukan penolakan dengan sikap pasif yaitu memeluk ibunya seolah enggan berpisah dan memilih duduk menyendiri di sudut kelas. Ketiga anak autis cenderung enggan melakukan kontak mata sebagai bentuk penolakan terhadap orang baru di sekitarnya. $M$ adalah salah satu anak autis yang masih mau melakukan kontak mata walaupun hanya pada saat namanya dipanggil dengan keras.

Bahasa non verbal lainnya ditunjukan dengan ekspresi wajah yang menggambarkan suasana hati setiap anak, diantaranya: murung, marah, dan senang. Seringkali anak autis dianggap sebagai anak yang sangat mudah marah dan ini tergambar dari gerak isyarat yang ditunjukan tubuh mereka. Hal ini pun terbukti dari penelitian yang dilakukan dimana saat anak merasa marah maka ia akan melakukan beberapa gerak isyarat, seperti: menangis, menendang meja, menjambak, mencubit dan menggit orang lain. Anak autis sangat jarang untuk mau berbicara sehingga paralanguage yang mereka tunjukan hanya sebatas dari pitch, volume dan kecepatan saat mengucapkan kata.

\section{DAFTAR PUSTAKA}

Admin KPAI. (2013). Undang-Undang RI No.23 Tahun 2002 tentang Perlindungan Anak. Retrieved Juny 07, 2018 from http://www.kpai.go.id/hukum/undang-undang-uu-ri-no-23-tahun-2002tentang-perlindungan-anak/

Ali, Mohammad dan Mohammad Asrori. (2009). Psikologi Remaja: Perkembangan Peserta Didik. Jakarta: PT.Bumi Aksara 
Budyatna, Muhammad dan Leila Mona Ganiem. (2011). Teori Komunikasi Antarpribadi. Jakarta: Kencana Media Group

Delphie, Bandi. (2009). Pendidikan Anak Autistik. Sleman : PT.Intan Sejati Klaten

Devito, A. Joseph. (1996). Human Communication. NewYork : HarperCollin Publishers

Littlejohn, Stephen W dan Foss KarenA. (2009). Theories of Human Communication. Newyork: Thomson Wardswordth.

Marijani, Leny. (2003). Bunga Rampai Seputar Anak Autis dan Permasalahannya. Jakarta : PT. AgroMedia Pustaka

Moustakas, Clark.(1994). Phenomenological Research Methods. California: SAGE Publication

Nugraheni. (2008). Sekilas Tentang Belantara Autisme. Semarang : Pustaka Zaman.

Prasetyono, Serba-Serbi Anak Autis (Mengenal, Menangani dan mengatasinya dengan Tepat dan Bijak). Yogyakarta : DIVA Press

Priyatna, Andri. (2010). Amazing Autism : Memahami, Mengasuh dan Mendidik Anak Autis. Jakarta: PT.Elex Media Komputindo

Purwanto. (2006). Ilmu Pendidikan Teoritis dan Praktis. Jakarta : Remaja Rosdakarya

Puspita, Dyah. (2004) . Untaian Duka Taburan Mutiara. Bandung:Qanita

Sukmadinata, Nana Syaodih. (2005). Landasan Psikologi Proses Pendidikan. Jakarta : PT.Remaja Rosdakarya

Yessi Cahaya. (2015). Jumlah Penderita Autis di Indonesia. Retrieved Juny 02, 2018 from https://klinikautis.com/2015/09/06/jumlah-penderita-autis-diindonesia/. 